DOI: $10.17516 / 1997-1370-0545$

УДК 811.111

\title{
Special. Phraseology in Business English Vocabulary: Forms and Functions
}

\author{
Tamara B. Nazarova* \\ Lomonosov Moscow State University \\ Moscow, Russian Federation
}

Received 02.10.2019, received in revised form 27.11.2019, accepted 27.12.2019

\begin{abstract}
The main focus of the article is a stratum within Business English vocabulary known as special phraseology and noted for the underlying fusion of terminological and metaphorical properties. The use of authentic samples of business discourse and the application of the corpora-based, descriptive, lexicographic, functional and quantitative methods allowed to uncover and present the systemic-structural, cognitive and functional characteristics of the stratum under analysis. The results of the study lead to a better understanding of the nature, scope, variety and functions of special phraseology as a low-frequency but dynamic and open-ended stratum of Business English vocabulary. As based on the material assembled and examined in the article, the list of the functional layers within Business English vocabulary has been expanded and therefore comprises 15 lexical, lexical-phraseological and terminological strata.
\end{abstract}

Keywords: Business English vocabulary, stratification, stratum/strata, special phraseology, form(s), function(s).

Research area: philology, English philology, Business English.

Citation: Nazarova, T.B. (2019). Special phraseology in Business English vocabulary: forms and functions. J. Sib. Fed. Univ. Humanit. Soc. Sci. DOI: 10.17516/1997-1370-0545.

\section{Introduction}

Business vocabulary and business discourse attract scholars and researchers around the world for a number of reasons. On the one hand, it is obvious that both fields of inquiry have not received all the attention they deserve, although the number of publications in this country and abroad - from articles to fullyfledged books - is on the increase in both the traditional and the online formats. On the other hand, business vocabulary and written as well as spoken business discourse are noted for their

(C) Siberian Federal University. All rights reserved

* Corresponding author E-mail address: tamara_nazarova@mail.ru ORCID: 0000-0002-6352-988X 
ability to react to constant and ongoing change in the world of business by generating new concepts and, as a result, coining new terms and terminological word-combinations that allow to verbalize them - "the addition of lexical items to meet the needs of changing times" (O'Dell, 2008: 94).

Business discourse comprises numerous texts written for the business community by theoreticians and practitioners with extensive in-depth knowledge of the old trends, new tendencies, current processes and innovative projects that take place in primary/secondary/ tertiary/quaternary industries across cultures on a day-to-day basis. Business discourse is not confined to written communication and covers numerous specimens of spoken discourse generated in a multitude of communicative settings by situated agents, representing companies, corporations, conglomerates, concerns, partnerships and small enterprises, as they interact face to face or over the telephone and establish, build up, maintain and consolidate business relationships.

Business discourse is being researched from different points of view by scholars interested in pragmatics and semiotics, morphology and syntax, functional styles and stylistics, written and spoken business communication. Of utmost significance for the present article is the lexicalphraseological aspect of business discourse and the fact that it incorporates, among other things, different lexical strata - terminological and non-terminological, neutral, formal and informal, monolexemic and polylexemic, highfrequency and low-frequency, well-known and recently created. The functional stratification carried out at the Lomonosov Moscow State University over the last 25 years allowed to uncover and account for 14 lexical strata (or lexical layers) in Business English vocabulary (Nazarova, 2014).

In what follows every stratum (or layer) is going to be named, described and exemplified. 1) General English words function across registers like Socializing for business purposes,
Telephoning for business purposes, Business letter-writing, Business documents and contracts, Business meetings, Presentations, and Negotiating for business purposes (e.g. to name, to call, to tell, to ask, nice, fine, etc.). 2) Formal vocabulary items create the muchneeded formal style of business correspondence, business documents and contracts (e.g. to terminate, to stipulate, to appreciate, etc.). 3) Core business terminology embraces a host of key business terms used in the world of business across sectors as a centripetal force holding isolated industries together (e.g. company, share, shareholder, management, manager, department, division, employer, employee, workforce, product(s), service(s), price, marketing, finance, personnel, human resources, recruitment, etc.). 4) Industryspecific terminological systems show the centrifugal force at work as they emphasize the difference between specialist areas, fields and domains (e.g. oil (gas) zone, oil content, oil derrick, oil desulfurization, etc. as the terms used in the oil and gas industry). 5) Special phraseology (or idiomatic terminology) is a borderline case between specialized conceptual layers (for example, core business terminology and industry-specific terminological systems) and non-specialist metaphorical uses of language (e.g. sleeping partner, loan shark, bull market, bear market, golden hello, golden parachute, etc.). 6) Business idioms are minimized in business discourse but some of them can recur in business-related contexts and situations (e.g. know/learn the ropes, show/teach someone the ropes, rock the boat, etc.). 7) High-frequency phrasal verbs are polylexemic items that are constituted by a monolexemic lexical verb and a particle (e.g. to set up, to spin off, to ward off, to fend off, to take on, to lay off, etc.). 8) Neologisms (and/ or occasionalisms) (e.g. boomerang C.E.O.s, guerrilla publicity, corporate citizenship, civil corporation, intellectual capital, talent management, etc.) show that business vocabulary is a dynamic ever-changing and 
open-ended entity offering increasingly more lexical innovations - both terminological and non-terminological. 9) Borrowings signal an ongoing conceptual and linguistic interaction between businesses and corporate cultures (see, for example, borrowings into Englishbased business vocabulary from the Japanese language - kaizen as in Companies that adopt kaizen can boost their productivity by as much as $30 \%$. or kanban as in kanban system). 10) Lexical items with vertical context come complete with literary and biblical associations that are needed to decode the specific meaning of the word or word-combination in the terminological system and numerous contexts of use (e.g. Lady Macbeth strategy, Gnomes of Zurich, Goldilocks economy, etc.). 11) Abbreviations are omnipresent and can be found in any of the lexical strata singled out in business vocabulary; they either accompany lexical items in their full form or replace them in suitable contexts of language use (e.g. plc/ public limited company, Ltd/limited, SMEs/ small and medium-sized enterprises, etc.). 12) Company names (e.g. companies from the global motor industry - General Motors, Ford Motor, DaimlerChrysler, Volkswagen, Honda, Nissan Motor, Fiat, PSA Peugeot Citroen, Renault or E-commerce companies - eBay, Expedia, Travelocity, Yahoo!, Amazon.com, Cisco, etc.). 13) Brands and brand names (the name a company gives to one of its products so that the product in question is differentiated and therefore recognizable). 14) Names of business thinkers and management giants, for example, the authoritative encyclopedia compiled for the world of business ("Business: The Ultimate Resource", 2002) names Peter F. Drucker - the management guru, Abraham Maslow with his theory of the "hierarchy of needs", Steve Jobs - co-founder of Apple Computer and one of the greatest technology entrepreneurs ever. Strata 12, 13 and 14 perform the semiotic function as the lexical items included in these strata identify, individualize and differentiate major players in business settings and business situations at large.

Some of these lexical strands have been reflected in the macro- and microstructure of the learner's bilingual Dictionary of General Business English Terminology (1st edition 2002, 2nd edition 2006); it contains over 850 headwords with their respective dictionary entries. Several strands (see 1, 2, 3, 4, 6 and 7 above) have been researched thoroughly and incorporated into learner-oriented coursebooks (Nazarova, 2014, 2009). The present article targets the stratum (see 5 above) that appears to be the least studied and the least clarified among the 14 strata listed above. There are several polylexemic terms used by Russian linguists to denote and refer to the stratum in question: special phraseology (or special phraseologisms), terminological phraseology (or terminological phraseologisms), idiomatic terminology (or idiomatic terms).

\section{Overview of literature}

The term special phraseology is a differentia specifica term derived from the genus proximum term phraseology. The latter denotes polylexemic lexical items that are recurrent, idiomatic and result from different degrees of metaphorization of their components. In the Russian lexicological and lexicographic tradition (Vinogradov, 1977), they have been classified and categorized as phraseological fusions, phraseological unities and phraseological combinations. In a similar fashion, special phraseology (or idiomatic terminology) covers recurrent multi-word combinations or sequences. These multi-word sequences, however, possess two important features that distinguish them from all other classes of polylexemic items: firstly, they have links with particular areas, industries and sectors in the world of business, and this feature is of semiotic significance; secondly, they display varying degrees of metaphorization in at least one of their two (or more) components, and these underlying metaphorical extensions 
bring them closer to idiomatic phraseology and idioms proper (Nazarova, 2006, 2009, 2014).

\section{Materials and methods}

The materials assembled and studied for the purposes of the present paper include authentic contexts and fully-fledged businessoriented articles from the quality print media. The aim of the study undertaken by the author is to bring together numerous uses of special phraseologisms so that their systemic and functional characteristics could be discovered, described and demonstrated not only from the point of view of linguistic theory, but also for further incorporation into the practical learneroriented language-teaching and languagelearning multi-strand syllabi within higher education curricula.

As far as methods are concerned, the list is selective and comprises the following methods as ways of ordering activity: the corpora-based method is most important because it prioritizes authenticity of language in use; the descriptive method allows to uncover the systemic morphosyntactic (or colligational) and lexical-phraseological (or collocational) characteristics of the lexical stratum under consideration; the lexicographic method gives one a much better understanding of the objective existence and status of the lexical items under analysis in the language system as reflected in and confirmed by the modern authoritative corpora-based unilingual dictionaries compiled by teams of expert lexicographers and eminent representatives of corpus linguistics; the functional method highlights the role and significance of the stratum under analysis in extended contexts of direct and indirect purposeful communication with particular attention to and emphasis on the different mixes, blends and amalgams of functions performed by special phraseologisms (terminological phraseologisms or idiomatic terms) in industry-specific business discourse; the quantitative method compares and contrasts individual special phraseologisms in terms of both frequency information in the lexicographic sources used for the purposes of the present paper and frequency of occurrence in authentic samples of business discourse studied at different stages in this research project.

What is explained above is now going to be corroborated and consolidated as based on the material selected for analysis and studied in detail with the help of the methods applied either one by one or in different combinations. The first step is to isolate a representative fragment of the material from an authoritative Business English dictionary. The fragment selected for the purposes of the present article includes $\mathbf{1 5 0}$ headwords (both monolexemic and polylexemic) under the letter $\mathbf{L}$ in the corpora-based unilingual Oxford Business English Dictionary, for example: lab, label, labor, labor agreement, laboratory, labor contract, laborer, labor union, labour, labour court, labour dispute, labourer, labour federation, labour force, labour-intensive, labour law, labour market, labour mobility, labour relations, labour-saving, ladder, laden, lading, lag, laggard, lagging indicator, laid-off, laissez-faire, lame duck, LAN, land, land bank, landed, landfill, landing, landing card, landing charge, landing page, etc. (Oxford Business English Dictionary, 2005: 306-308). The next step of the analysis centres on stratification: 150 lexical items are studied in detail and shown to belong to different lexical strata (General English words, formal vocabulary items, core business terminology, industryspecific terminology, special phraseology, business idioms, phrasal verbs, etc.).

Out of these 150 headwords under the letter $\mathbf{L}$, only $\mathbf{1 0}$ items are categorized as special phraseologisms - lexical items that have both essential characteristics: an objective and demonstrable link with at least one of the business-related terminological systems, on the one hand, and a certain amount (or degree) of metaphorization in one or more of their components, on the other hand. The special phraseologisms under analysis are as follows: 
lame duck, landing page, laundry list, late majority, latent defect, lightning strike, loan shark, low-hanging fruit, low road, lump sum. Two types of morphosyntactic patterning are observable in the material: adjective + noun and noun + noun.

As mentioned above, the special phraseologisms in the list under consideration display indissoluble links with the terminology (and terminologies) of the world of business, for example: lame duck is linked with the terms company (as a matter of fact, an ailing company) and industry (for example, lameduck industries); late majority is defined as "the group of customers who will only start to use a new product after many other people are using it" and therefore has close ties with terms like customer and product. Within the terminological system, late majority has acquired an antonym early majority. The same applies to low road (e.g. a low-road company) with its antonym high road (e.g. build a high-road tyre company). Some of the special phraseologisms under analysis have synonyms, for example: hidden defect and patent defect are synonyms of latent defect. Some of the terminological phraseologisms in the above list of 10 polylexemic items have neither synonyms nor antonyms, for example: laundry list, lightning strike, loan shark. All of them, however, display varying degrees of metaphorization. For example: low-hanging fruit as a terminological phraseologism has got nothing to do with fruit of any kind; it refers to easy ways of increasing profits, cutting costs, etc. as in "At a time when companies all want to seem green, packaging is a low-hanging fruit." (Cambridge Business English Dictionary) Loan shark defined as "a person who lends money at very high rates of interest" follows the nominative-derivative meaning of its General English counterpart shark - "informal someone who gets money by cheating people". Loan shark in business vocabulary retains its stylistic and pragmatic properties as both informal and showing disapproval.
On having covered the lexicographic material with 150 headwords and 10 special phraseologisms, the research study enters the stage when terminological phraseologisms are to be looked at in business-related contexts and, wider, authentic business discourse. This step in the study of the stratum under analysis involves fully-fledged business-oriented articles from the quality print media. The first set of contexts comes from The Moscow Laundromat published in The NEW YORKER Magazine (July 30, 2017). The list of the special phraseologisms used in this 1500-word article comprises 6 polylexemic lexical items: money laundering, anti-money laundering, mirror trade(s), mirrortrading, mirror order, capital flight.

All the items gleaned from the authentic article display varying degrees of terminological definability and metaphorization. These features make this list compatible with the list of headwords from the corpora-based unilingual Business English dictionary presented earlier. There is another objective parameter that makes the two lists even more compatible: the stratum in question is also shown to be a low-frequency stratum, for some of the 6 polylexemic lexical items given above occur in the material only once (e.g. anti-money laundering, mirror order) or several times (e.g. mirror trading - 2; money laundering - 3; capital flight -5 ).

The only special phraseologism noted for frequency of occurrence in the business-related article under analysis and at the same time not registered in any of the available corpora-based Business English dictionaries is mirror trade (see 2, 3, 4, and 6 below) or mirror trading (see 1 and 14 below). The notion occurs in different forms and shapes 48 times, and, most interestingly, displays an impressive range of derivational, colligational and collocational patterns. Mirror trade is used mostly in the plural form, but it can also occur in the singular form (compare, for example, 2, 3, 4, and 15 below). Mirror trade is a compound following the colligational pattern noun + noun, but it also develops an occasional lexical-grammatical 
homonym mirror-trade (and mirror-trades) as adjective (see 5, 10, 16, 18 below). From the lexical-phraseological (or collocational) point of view, the special phraseologism mirror trade collocates with verbs like work, execute, know (about), speak (to someone about), ask (someone about), implicate (in), initiate, use, look into; it also collocates with adjectives and nouns (see 2, 9, 11, 12 and 17 below). The occasional adjective mirrortrade combines with several nouns (see 5, 10, 16,18 below). What is given below is a listing of 14 short excerpts from the authentic businessoriented article selected for the purposes of the present inquiry into the systemic and functional characteristics of special phraseology as a strand within business vocabulary:

1) In the English-language media, the scheme has become known as "mirror trading".

2) Fourteen former and current employees of Deutsche Bank in Moscow spoke to me about the mirror trades..

3) Viewed with detachment, however, repeated mirror trades suggest a sustained plot to shift and hide money of possibly dubious origin.

4) ...three members of its Russian equities desk were suspended for their role in mirror trades ...

5) In April, 2015, the mirror-trades scheme unravelled.

6) ...some of the money diverted through mirror trades belonged to ...

7) ...with pressure from shareholders intensifying over mirror trades ...

8) Mirror trading was an ideal escape tunnel.

9) According to people with knowledge of how mirror trades worked at ...

10) ...became one of the first major mirrortrade clients.

11) ...also began executing mirror trades for several other companies.

12) Colleagues also remember that Hayes asked both Buznik and Wizwell about the mirror trades.
13) Several Deutsche bank employees in London knew about the mirror trades ...

14) ...to discuss the propriety of mirror trading.

15) ...the Russian side of a mirror trade ...

16) ...had barred two mirror-trade counterparties ... from improperly using the stock market to send money overseas.

17) ...the true purpose of the mirror trades was to facilitate capital flight.

18) Another British mirror-trade entity ... was registered in the same office ...

19) ...another Russian brokerage implicated in mirror trades ...

20) ...took commissions for initiating mirror trades on behalf of rich people and businesses eager to send their money offshore.

21) ...the footprint of individual mirror trades was small.

22) Mirror trades never exceeded twenty million dollars a day ...

23) ... another bank picked up the mirror order ...

24) In April, I met a broker in Moscow who had worked with clients of the Deutsche Bank mirror trades.

The two compounds mirror trade and mirror trading are at the crossroads of the four strata in business vocabulary presented above. Firstly, they have links with the key concepts and core terms of the world of business (see stratum 3 above), for example: the stock market, money, capital, commission, business, client, order, bank, transaction. Secondly, they display a metaphorical transference of meaning (mirror in this case goes well beyond the nominative meaning of the counterpart word in General English), and this fact places the two polylexemic terminological combinations within the stratum known as special phraseology (see stratum 5 above). Thirdly, mirror trade(s) and mirror trading are newcomers not registered in any of the authoritative corpora-based dictionaries available at the time of writing, and can therefore be seen as neologisms (see stratum 8 above). 
Fourthly, mirror trade(s) and mirror trading have also got industry-specific associations as they recur in the contexts related to investing, banking, and the stock market; these semiotic properties are shared by special phraseology with industry-specific terminologies (see stratum 4 in the list of the 14 strata offered in the second subsection of the present article).

\section{Results and discussion}

The material adduced above was studied in detail with the help of the methods selected for the purposes of the present inquiry into the status, structure and scope of one lexical stratum within business vocabulary. The study of the lexicographic material shows that the lexical stratum under consideration is a lowfrequency layer in the representative fragment of 150 headwords (with their dictionary entries) borrowed from the authoritative corpora-based unilingual Business English dictionary as there were only 10 items that could be categorized as special phraseologisms. These 10 polylexemic units were subjected to a step-by-step in-depth analysis that revealed in every one of them a mix, blend or amalgam of the two essential characteristics - a demonstrable link with one or several terminological strata (core business terminology, on the one hand, and/or industryspecific terminological systems, on the other hand) and varying degrees of metaphorization in their components.

The contexts of use borrowed from an authentic business-related article confirmed that the stratum in question is not noted for frequency of occurrence and to a large extent remains to be a low-frequency lexical layer. The special phraseologism mirror trade(s) is an exception because it recurs in at least 48 contexts and displays a wide range of derivational, colligational and collocational flexibility. What is of interest here is that in the better part of the contexts gleaned from the authentic article this terminological phraseologism carries negative connotations: it is accompanied by phrases, expressions and utterances like sleight of hand, a sustained plot to shift and hide money of possibly dubious origin, suspended for their role in the mirror trades, spirited out of ... through the scheme, the mirror-trades scheme unravelled, diverted through mirror trades, with pressure from shareholders intensifying over the mirror trades and other scandals, an ideal escape tunnel, discuss the propriety of mirror trading, facilitate capital flight, the mirror-trades scandal, the mirror-trading scandal.

The above observation makes it possible to add another layer to the stratification of Business English vocabulary undertaken by the author of the present article and effected over the last 25 years with a resultant list of 14 strata. This additional stratum could embrace lexical and terminological items with a host of expressive-emotionalevaluative overtones or connotations. Mirror trades and mirror trading come complete with pejorative connotations, and in this sense they can join the terms shown to have acquired negative connotations for a number of reasons: conglomerate ("sprawling conglomerates" rating size over efficiency and productivity), globalization (the great drama of the globalization era, "Globalization and its Discontents" by a Nobel Prize winning Columbia professor Joseph Stiglitz), team (and teamwork) ("loose networks", "the fleeting forms of association"), consultant, consulting ("Lying, cheating and stealing are standard practice in the consulting business.") (Sennett, 1998; Pinault, 2000; Nazarova, 2014).

As far as the functional aspect is concerned, although special phraseologisms are shown to belong to a low-frequency lexical (and terminological) layer, they perform a host of functions. First and foremost, they help to compress what is being said semantically, and this is the function of semantic compression: the writer uses fewer words to express a particular meaning, purport, content or implication; 
compare mirror trading, on the one hand, and a wordier explanation of what it stands for ("a sustained plot to shift and hide money of possibly dubious origin"), on the other hand. The next two functions do not contradict the first one. As a matter of fact, they follow from and more often than not accompany the function of semantic compression: every time a special phraseologism is used, speech becomes both more laconic and more idiomatic. The fourth function brings terminological phraseologisms closer to the euphemistic resources of the language system and, wider, communication culture: from the communicative, pragmatic and cognitive point of view, there is an obvious difference between mirror trading (or mirror trades) and "facilitating capital flight" ("spiriting billions of dollars through the scheme" or "sending money offshore through less traceable transactions"); special phraseologisms appear suitably indirect and vague, whereas the short utterances given in double quotes are too direct and as such convey straightforwardly pejorative overtones and connotations. The fifth function is semiotic: because of their terminological components and terminological links special phraseologisms place (or situate) the user of written and/or spoken discourse as a representative of a particular sphere, industry or sector within the world of business.

The next set of contexts contains another special phraseologism capital flight and can help illustrate the functions presented above.

1) ...the true purpose of mirror trades is to facilitate capital flight.

2) In a connected and digitized financial system, how could such capital flight happen?

3) The impact of this capital flight is felt at both ends of its journey.

4) ...the unrecorded capital flight from... included criminal activity such as tax evasion and money laundering.

Capital flight means "a situation in which large amounts of money are sent out of a country to be kept or invested in other countries, for example, because of fears about the economy" (Cambridge Business English Dictionary, 2005: 109). This special phraseologism conveys the bulk of the conceptual material it stands for in a semantically compressed form, making the text more laconic, less straightforward and more idiomatic. The negative overtones are retained in the text through the collocates (see the verb facilitate in 1 above and the adjective unrecorded in 4 above) and links with criminal activity, tax evasion and money laundering (see 4 above).

\section{Conclusion}

The stratum selected and studied for the purposes of the present article stands out among the 14 lexical (and terminological) layers arrived at through step-by-step functional stratification carried out over the course of the last 25 years at the Department of English Linguistics (Faculty of Philology, Lomonosov Moscow State University). The lexical items assembled under the heading of special phraseology are noted for the combination of the two essential characteristics - the links with a terminological system employed within a particular industry or across industries, on the one hand, and an underlying transference of meaning, on the other hand. Special phraseologisms perform a number of functions in business discourse. These functions are interconnected and range from the semiotic function that situates the language users in particular industries within the world of business to the euphemistic function that makes business discourse less direct and increasingly more roundabout. The material studied with the help of a set of methods (corpora-based, descriptive, lexicographic, functional, quantitative) shows that special phraseology is a low-frequency stratum that makes speech more laconic and more idiomatic.

The study carried out using authentic material - both lexicographic and textual makes it possible to expand the list of $\mathbf{1 4}$ lexical 
strata adduced above by adding a new stratum that comprises connotative monolexemic and polylexemic terms. The resultant inventory of 15 lexical strata could be further incorporated into the new edition of the English-Russian dictionary for advanced learners of Business English. Its first edition came out in 2002 and demonstrated 5 techniques of systematic business vocabulary extension: naming the headword with its regional synonyms and/or abbreviations; defining the term in English; translating the term into Russian; defining the headword in Russian; offering recurrent collocations and contexts to show how the monolexemic or polylexemic term can be used in business settings and situations across national and corporate cultures. These techniques allow to bridge the gap between theory and practice, and also transform language users into effective communicators "able to navigate, with confidence and competence, ... the wide lexical ocean" with "a good command of a much more varied and specialized vocabulary" (Stein, 2008: 181).

\section{Acknowledgements}

I would like to thank all the undergraduate and postgraduate students of the Department of English Linguistics at the Faculty of Philology, Lomonosov Moscow State University, who have enthusiastically attended my special seminars and special courses over the past 25-30 years, showing genuine interest in research work and continuing commitment to ongoing foreign language acquisition.

I am indebted to the publishers in the Russian Federation who made it possible to share knowledge, ideas and materials through the books and dictionaries they published in both English and Russian.

I am very happy to have had numerous opportunities to discuss a wide range of linguistic and philological subjects with my colleagues within and outside the Lomonosov Moscow State University as a plenary speaker at international conferences and an active participant of the Business English Special Interest Group discussions.

\section{References}

Business: The Ultimate Resource (2002). Cambridge, MA, Perseus Publishing, 2174 p.

Cambridge Business English Dictionary (2011). Cambridge, Cambridge University Press, 947 p.

Nazarova, T.B. (2 ${ }^{\text {nd }}$ edn, 2009). Business English. A Course of Lectures with Exercises, Activities, and Tasks. Moscow, AST/Astrel, $272 \mathrm{p}$.

Nazarova, T.B. (2 $2^{\text {nd }}$ edn, 2006). Dictionary of General Business English Terminology. Moscow, AST/ Astrel, 128 p.

Nazarova, T.B. (2014). Core business terminology and connotation. In Larissa A. Manerko, Klaus-Dieter Baumann, Hartwig Kalverkamper (Eds.), Terminology Science in Russia Today. From the Past to the Future. Berlin, Frank \& Timme, 205-209.

O’Dell, F. (2018). (January 2016). Creating new words: affixation in neologisms. In ELT Journal, 70/1, 94-99.

Pinault, L. (2000). Consulting Demons. Inside the Unscrupulous World of Global Corporate Consulting. New York, HarperCollins Publishers, 288 p.

Sennett, R. (1998). The Corrosion of Character. The Personal Consequences of Work in the New Capitalism. New York, W.W. Norton \& Company, 176 p.

Stein, G. (2008). Developing Your English Vocabulary. A Systematic New Approach. Second Impression. Tubingen, StauFFenburg Linguistik, $272 \mathrm{p}$.

Stiglitz, J. (2002). Globalization and Its Discontents. New York, W.W. Norton \& Company, 282 p.

Oxford Business English Dictionary (2005). Oxford, Oxford University Press, 616 p.

Vinogradov, V.V. (1977). Ob osnovnykh tipakh frazeologicheskikh edinitz v russkom iazyke [On the Basic Types of Phraseological Units in the Russian Language]. In Izbrannye trudy. Leksikologiia i leksikogra iia [Selected works. Lexicology and Lexicography], 140-161. 


\title{
Специальная фразеология в словарном составе английского языка делового общения: формы и функции
}

\section{Т.Б. Назарова}

Московский государственный университет имени М.В. Ломоносова Российская Федерачия, Москва

\begin{abstract}
Аннотация. В статье рассматривается одна из страт в словарном составе английского языка делового общения, именуемая специальной фразеологией и привлекающая особое внимание специалистов-исследователей вследствие неразрывной связи терминологических и метафорических свойств. Использование разнообразного аутентичного материала и применение сочетания таких методов, как корпусный, описательный, лексикографический, функциональный и квантитативный, позволили выявить и обобщить с научно-теоретической и практической точек зрения основополагающие системно-структурные, когнитивные и функциональные особенности этого пласта в лексике бизнес-английского. С опорой на образцы современного речеупотребления перечень функциональных страт в словарном составе делового английского был расширен и дополнен еще одной стратой, что делает вполне обоснованным утверждение о том, что в деловом общении на современном английском языке задействовано не менее 15 лексических и терминологических пластов.
\end{abstract}

Ключевые слова: словарный состав английского языка делового общения, стратификация, страта, пласт, специальная фразеология, форма, функция.

Научная специальность: 10.02.04 - германские языки. Английская филология. Английский язык делового общения. 